\title{
Pasture production gains from strategic winter nitrogen applications on a North Island sheep and beef hill country farm
}

\author{
M.R. PUHA ${ }^{1}$, W.McG. KING ${ }^{1}$, V.T. BURGGRAAF ${ }^{1}$ and A.H.C. ROBERTS ${ }^{2}$ \\ ${ }^{1}$ AgResearch, Ruakura Research Centre, PB 3123, Hamilton \\ ${ }^{2}$ Ravensdown, PO Box 608, Pukekohe \\ warren.king@agresearch.co.nz
}

\begin{abstract}
Inadequate pasture growth from September to November has been a major constraint on animal production at Limestone Downs, Port Waikato. In an attempt to address this, urea was applied by air in two applications per year (late autumn + winter) at rates up to $250 \mathrm{~kg} \mathrm{~N} / \mathrm{ha} /$ year for each of 3 years (2004-2007). Pasture production, botanical composition and $\mathrm{N}$ concentration in leachate were determined on a range of slopes and aspects. Average $\mathrm{N}$ fertiliser response for the 3 years of the trial was, respectively, 18.9, 15.7 and 13.6 $\mathrm{kg} \mathrm{DM} / \mathrm{kg} \mathrm{N}$ applied. Easy northerly slopes and southerly aspects showed strong positive responses to $\mathrm{N}$ application for all 3 years while moderate to steep northerly slopes showed smaller, inconsistent responses. Leachate $\mathrm{N}$ concentration was always higher in fertilised paddocks but values varied annually and with slope and aspect. Strategic use of high rates of N fertiliser use in hill country should ideally concentrate on areas showing a strong positive pasture growth response with limited $\mathrm{N}$ loss from leachate. At Limestone Downs, areas with little slope showed strong pasture growth responses but increased leachate $\mathrm{N}$ concentration while moderate southerly aspects had lower increases in leachate $\mathrm{N}$ concentration but only moderate pasture growth responses.
\end{abstract}

Key words: nitrogen, slope, aspect, pasture growth, fertiliser response

\section{Introduction}

Poor pasture growth from late winter to early spring was identified as one of the main limitations to animal production at Limestone Downs sheep and beef station, Port Waikato. The application of nitrogen fertiliser, particularly if strategically placed on certain slopes and aspects during winter, has the potential to overcome this constraint (Gillingham et al. 1998; Luscombe 1979; Lambert \& Clark 1986). Given the difficult topography and the requirement to apply the fertiliser by air, few applications at high rates are the only feasible option. However, the resulting intensification of land use could lead to greater off-farm nitrogen losses in water and doubts about the long-term sustainability of such a practice (Lambert et al. 2003). This study was undertaken to determine the pasture production response to $\mathrm{N}$-fertiliser application while simultaneously measuring the $\mathrm{N}$ being leached through the soil.

\section{Methods}

Four pairs of adjacent paddocks were selected with similar aspect and slope:

1. South-facing moderate slope

2. North-facing moderate slope

3. North-facing easy slope

4. North-facing steep slope

The 'easy' slopes were $<18^{\circ}$, 'moderate' slopes approximately $10-25^{\circ}$ and 'steep' slopes $21-43^{\circ}$. From each pair of paddocks, one was fertilised. Nitrogen was applied by aerial topdressing on 9 June $2004(100 \mathrm{~kg} \mathrm{~N} /$ ha as urea), 10 August 2004 (150 kg N/ha as urea), 8 June 2005 (100 kg N/ha as urea), 3 August 2005 (80 kg $\mathrm{N} / \mathrm{ha}$ as urea), 15 August 2005 (20 kg N/ha as DAP), 26 June 2006 (100 kg N/ha as urea) and 24 July 2006 (100 $\mathrm{kg} \mathrm{N} / \mathrm{ha}$ as urea) to 700 ha of the farm. Paddocks were grazed by sheep and cattle.

\section{Pasture measurements}

Pasture production was monitored using grazing exclusion cages and a trim-harvest technique. Five cages were placed in each paddock, with the exception of one of the northerly facing pairs, where five cages were placed on an easy slope area and five on a steep area in each paddock. Cages were initially placed on 1 June 2004 and pasture was harvested within these 28 times through to 17 May 2007. Within each cage, a $0.125 \mathrm{~m}^{2}$ area was cut to a residual of $15 \mathrm{~mm}$ for estimation of dry matter (DM) production. The cage was then re-sited on a similar slope, where possible avoiding areas that were obviously pugged or locally dominated by weeds, and trimmed to $15 \mathrm{~mm}$.

On 18 occasions (during and following the $\mathrm{N}$ response period), the herbage within the cage that was not used for DM estimation was cut to $15 \mathrm{~mm}$ and assessed for botanical composition. Herbage was bulked within aspect/slope class and paddock, giving eight samples per visit. Each sample was dissected into perennial grasses (excluding kikuyu), kikuyu, legumes, broadleaved weeds and dead matter, then dried and weighed. 


\section{N leaching}

A total of 62 lysimeters were set up in August 2004 on similar slopes to the companion grazing exclusion cages. Each lysimeter was $15 \mathrm{~cm}$ in diameter and $30 \mathrm{~cm}$ deep and was connected to a $4300 \mathrm{ml}$ collection reservoir. Eight lysimeters were installed in each paddock/slope class, with the exception of two paddocks that had only seven because the very shallow A-horizon and saturated B-horizon in these paddocks made installation extremely difficult. Obvious stock camps were avoided.

Leachate was manually collected on the same day as pasture measurements were taken and also in response to significant rainfall events. The volume of leachate was measured, sub-sampled, and the remaining leachate was discarded. Total volume would be obviously underestimated if the volume of leachate exceeded the capacity of the collection vessel. At each sampling time, subsamples for each paddock were bulked for analysis of nitrate and ammonium-N concentration. The volume of each sub-sample that was incorporated into the bulked sample was weighted by the total volume of leachate collected.

\section{Data analysis}

Data were analysed by Analysis of Variance using Genstat (Version 9). Each pair of paddocks was used as a replicate - a total of four replicates. The 'block' effect was extracted during analysis. Leachate data were log transformed before analysis because of the skewed data distribution, but the results presented are untransformed means.

\section{Results and Discussion Pasture production}

Dry matter yields in nitrogen-fertilised paddocks were substantially greater than non-fertilised paddocks (Fig. 1, Table 1). Annual dry matter yields ranged from 6.3 to 13.2 $\mathrm{t} \mathrm{DM} /$ ha across the $\mathrm{N}$-fertilised sites, and from 4.1 to $12.0 \mathrm{t} \mathrm{DM} /$ ha on the unfertilised sites. Statistically

Figure 1 Average pasture cover through time in fertilised and unfertilised plots.

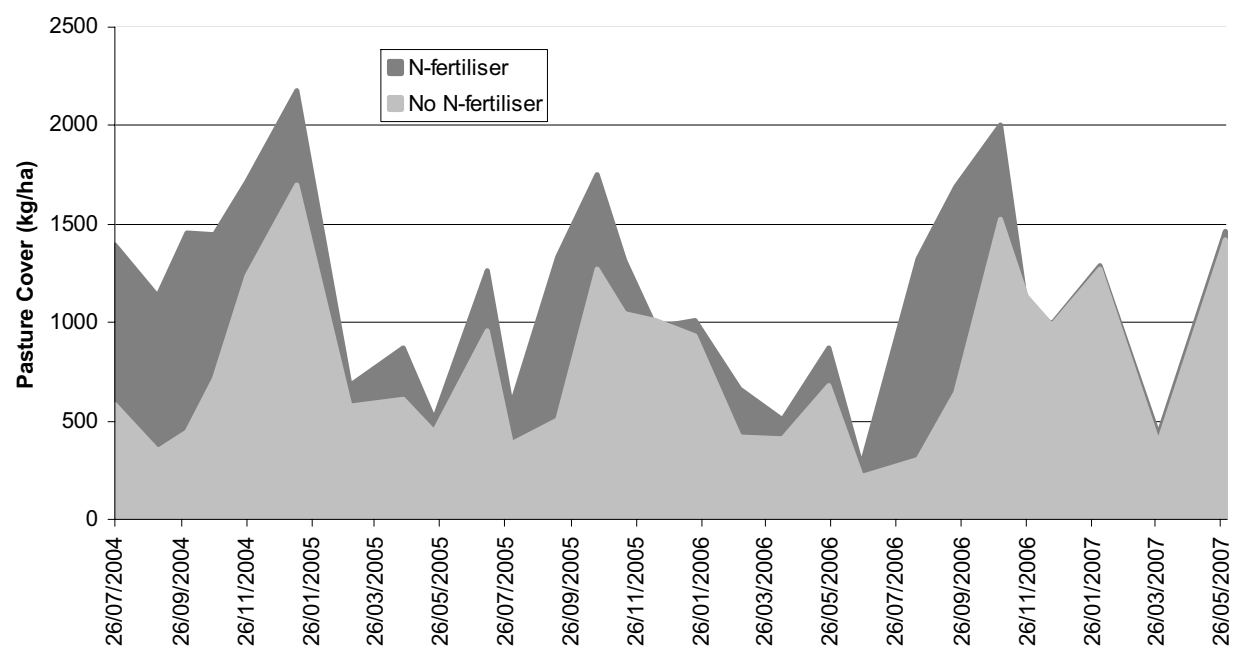

Table 1 Annual pasture production ( $\mathrm{kgDM} / \mathrm{ha})$ for fertilised and unfertilised paddocks for each growing season.

\begin{tabular}{cllcccc}
\hline & & & \multicolumn{3}{c}{ Growing Season } & \multicolumn{3}{c}{ 3-yr } \\
\cline { 5 - 7 } Paddock\# & Slope/Aspect & Treatment & 04-05 & 05-06 & 06-07 & average \\
\hline 10 & Moderate southerly & No N & 6330 & 6450 & 5910 & 6230 \\
9 & Moderate southerly & N & 11150 & 11070 & 8420 & 10210 \\
18 & Moderate northerly & No N & 8680 & 10850 & 11980 & 10500 \\
17 & Moderate northerly & N & 11980 & 10550 & 11700 & 11410 \\
51 & Easy northerly & No N & 7590 & 8820 & 7600 & 8000 \\
52 & Easy northerly & N & 15720 & 13230 & 13030 & 13990 \\
$51 a$ & Steep northerly & No N & 4060 & 4380 & 6020 & 4820 \\
$52 a$ & Steep northerly & N & 6670 & 6250 & 9030 & 7320 \\
& & Average No N & 6660 & 7630 & 7880 & 7390 \\
& & Average N* & 11380 & 10280 & 10540 & 10730 \\
\hline
\end{tabular}

* Differences between average pasture production for the $\mathrm{N}$ and No $\mathrm{N}$ paddocks within each growing season were not statistically significant $(P>0.05)$. 
significant $(\mathrm{P}<0.05)$ differences emerged between the fertilised and unfertilised plots in late winter/early spring for each of the 3 years. There were substantial differences in pasture production with slope/aspect e.g. steep northerly paddocks consistently yielded about $45 \%$ less than moderately sloping northerly paddocks.

The average $\mathrm{N}$ fertiliser response across sites was $18.9 \mathrm{~kg} \mathrm{DM} / \mathrm{kg} \mathrm{N}$ applied in the first year, $15.7 \mathrm{~kg} \mathrm{DM} /$ $\mathrm{kg} \mathrm{N}$ applied in the second year and $13.6 \mathrm{~kg} \mathrm{DM} / \mathrm{kg} \mathrm{N}$ applied in the last year. This is within the range of 7-33 $\mathrm{kg} \mathrm{DM} / \mathrm{kg} \mathrm{N}$ measured across a range of hill country experiments (Ball et al. 1982), and greater than the $10 \mathrm{~kg}$ $\mathrm{DM} / \mathrm{kg} \mathrm{N}$ from Waikato dairy pastures receiving $200 \mathrm{~kg}$ $\mathrm{N} /$ ha/year (Ledgard et al. 2001). Differences between years could be due to a range of climate, soil and grazing management factors.

The relatively low average $\mathrm{N}$ response is partly attributable to a very low response on north-facing plots with moderate or steep slopes. While the south-facing and flatter north-facing plots showed $\mathrm{N}$ responses of 18.3 and $27.7 \mathrm{~kg} \mathrm{DM} / \mathrm{kg} \mathrm{N}$, averaged over 3 years, the moderately sloping and steep north-facing plots had responses of only 2.9 and $11.3 \mathrm{~kg} \mathrm{DM} / \mathrm{kg} \mathrm{N}$, respectively. We have no explanation for this result. When comparing results between slopes and aspects, it should be remembered that there was no replication of aspect, and differences could potentially be due to different soil types, depths, moisture status, grazing management and pasture composition. Ledgard et al. (1983) concluded that, in order to obtain maximum pasture responses to $\mathrm{N}$ fertiliser in hill country, priority should be given to dense, ryegrassdominant, easy slopes. However, subsequent work at Ballantrae in the Manawatu region, showed equally large $\mathrm{N}$ responses from lower fertility grass-dominant pastures on steeper slopes (G. Lambert pers. comm.). Our results indicated that aspect, as well as slope, have a strong influence on response to $\mathrm{N}$ fertiliser at Limestone Downs.

\section{Pasture species composition}

There were no significant differences detected in species composition between paddocks that did or did not receive $\mathrm{N}$ fertiliser (Fig. 2). There was some suggestion of a decline in perennial grass content towards the end of the experiment, particularly in the No N paddocks. Ryegrass content was lower in summer and autumn, as a result of an invasion of flat-weeds and summer grasses. Rat's tail (Sporobolus africanus) was present on steep slopes, and kikuyu (Pennisetum clandestinum) was present at all of the north-facing sites in late summer and autumn. Legume content generally remained below $10 \%$ of pasture cover throughout the year.

\section{N leaching}

More than 1800 individual samples were collected over the period of the trial. Less than $6 \%$ of these samples had overflowed the collection vessel $(>4300 \mathrm{ml})$ and the underestimation of total leachate volume is not considered significant. The values presented here for leaching of $\mathrm{N}$, however, should be interpreted with caution. The leachate was collected from $30 \mathrm{~cm}$ below the soil surface and a proportion of this may well be captured by plant roots or immobilised by soil bacteria below that depth, preventing it from reaching ground water. This also makes extrapolation of $\mathrm{N}$ leaching to a whole farm scale unfeasible.

Consistently higher leachate $\mathrm{N}$ concentrations were measured from paddocks receiving nitrogen fertiliser. Over the 3 years of the trial, the average total $\mathrm{N}$ concentration in the leachate from the $\mathrm{N}$ fertilised plots was $18 \mathrm{mg} / \mathrm{L}$ (Table 2). The leachate from the unfertilised paddocks had $\mathrm{N}$ concentrations with an average of 5.2 $\mathrm{mg} / \mathrm{L}, 70 \%$ lower than the fertilised paddocks $(\mathrm{P}<0.05)$. However, very high variability meant that treatment differences in leaching rates at each sampling event were only rarely statistically significant.

There was substantial year-to-year variation in leachate N concentration: in the 2005-2006 season, the fertilised plots had leachate $\mathrm{N}$ concentrations more than double that in 2006-2007 (Table 2). The total volume of leachate was also greater in 2005-2006 and nearly $60 \%$ of overflowed leachate collection vessels occurred in this one season. This may be due to the higher rainfall experienced in the 2005/2006 season: $25 \%$ more rainfall than in either 2004-2005 or 2006-2007 (1458 mm vs. 1166 and $1167 \mathrm{~mm}$, respectively). Results from lysimeter measurements at Ballantrae and Invermay as part of the Wise N project (www.wisenuse.co.nz) also showed high values for 2005-2006. There were also substantial differences in leachate $\mathrm{N}$ concentration with slope/aspect: steep northerly paddocks consistently showed concentrations about $70 \%$ lower than easy northerly paddocks.

Previous work has indicated that direct leaching of fertiliser $\mathrm{N}$ is usually low, except from applications in late-autumn/winter, when losses may be up to one-third of $\mathrm{N}$ applied (Ledgard et al. 1988). The effects of winter application on direct leaching in this study could have been exacerbated by the high rates of $\mathrm{N}$ per application (up to $150 \mathrm{~kg} / \mathrm{ha}$ ). Typical recommendations for $\mathrm{N}$ fertiliser are to apply no more than about $50 \mathrm{~kg} \mathrm{~N} / \mathrm{ha} /$ application. This rate provides maximum pasture response and minimises $\mathrm{N}$ losses but requires repeated applications. However, this recommendation has been developed in easier downlands environments and the impracticality of frequent applications of lower rates of $\mathrm{N}$ on hill country means that a different application strategy is required.

Most $\mathrm{N}$ leaching occurs from animal urine patches (Ledgard 2001), with greater $\mathrm{N}$ leaching occurring under 
Figure 2 Average botanical composition (as a percentage of total dry matter) of fertilised (a) and unfertilised (b) paddocks.
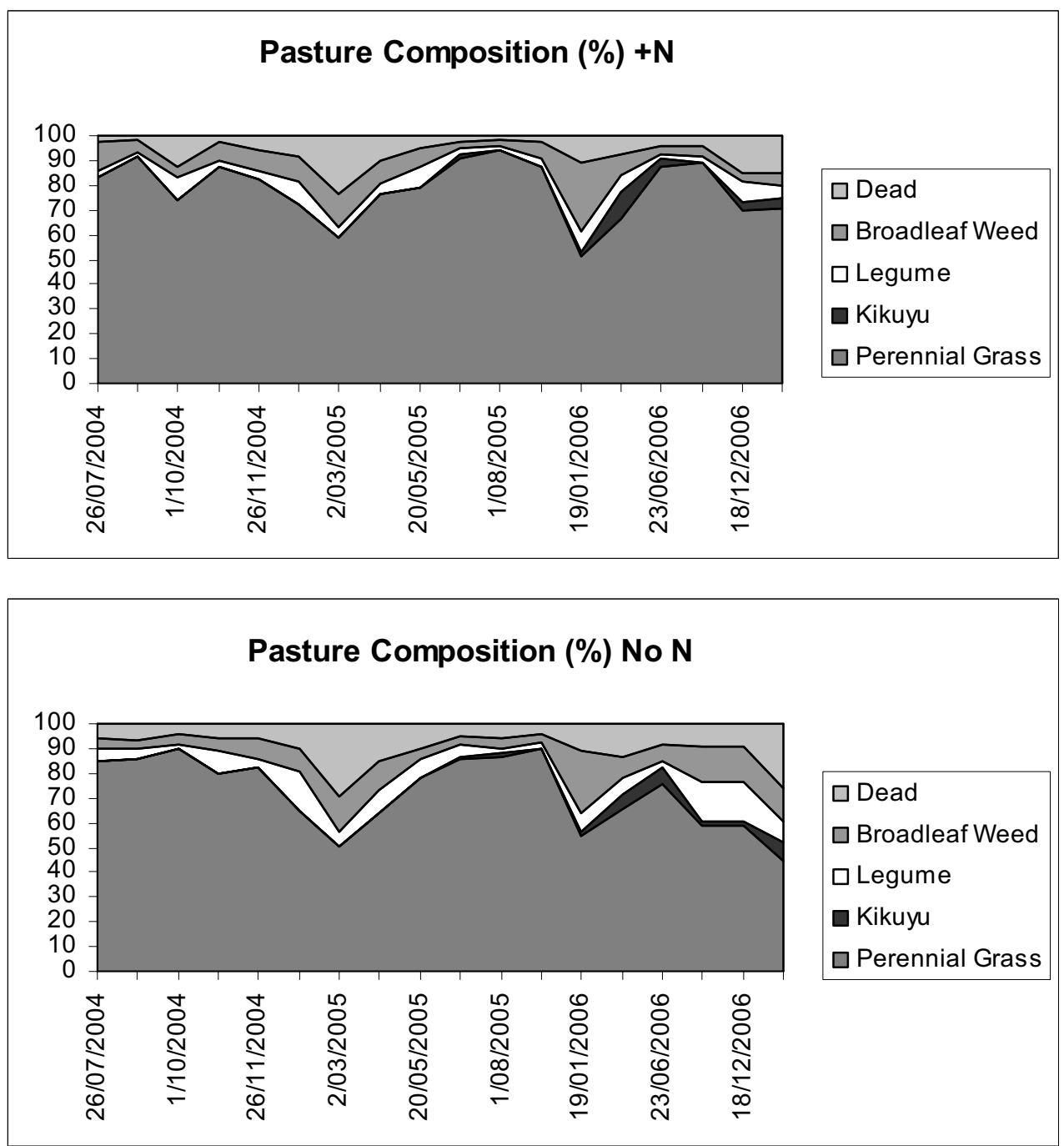

Table 2 Average leachate nitrogen concentration (mg N/L - NH $\left.\mathrm{H}_{3}+\mathrm{NO}_{3}+\mathrm{NO}_{2}\right)$ for each growing season on varying slope classes and aspects of paddocks with and without nitrogen fertiliser application.

\begin{tabular}{|c|c|c|c|c|c|c|}
\hline \multirow[b]{2}{*}{ Paddock\# } & \multirow[b]{2}{*}{ Slope/Aspect } & \multirow[b]{2}{*}{ Treatment } & \multicolumn{3}{|c|}{ Growing Season } & \multirow{2}{*}{$\begin{array}{c}3-y r \\
\text { average }\end{array}$} \\
\hline & & & 04-05 & $05-06$ & $06-07$ & \\
\hline 10 & Moderate southerly & No $\mathrm{N}$ & 3.9 & 2.4 & 1.2 & 2.5 \\
\hline 9 & Moderate southerly & $\mathrm{N}$ & 13.1 & 9.3 & 3.8 & 8.7 \\
\hline 18 & Moderate northerly & No $N$ & 7.3 & 11.4 & 5.8 & 8.2 \\
\hline 17 & Moderate northerly & $\mathrm{N}$ & 27.7 & 18.2 & 11.2 & 19.0 \\
\hline 51 & Easy northerly & No $N$ & 5.3 & 8.3 & 5.5 & 6.4 \\
\hline 52 & Easy northerly & $\mathrm{N}$ & 24.5 & 61.9 & 21.0 & 35.8 \\
\hline $51 a$ & Steep northerly & No $N$ & 3.9 & 5.0 & 2.0 & 3.6 \\
\hline \multirow[t]{3}{*}{$52 a$} & Steep northerly & $\mathrm{N}$ & 13.4 & 8.7 & 3.2 & 8.4 \\
\hline & & Average No $\mathrm{N}$ & 5.1 & 6.8 & 3.6 & 5.2 \\
\hline & & Average $\mathrm{N}$ & $19.7^{\star \star *}$ & 24.5 & $9.8^{*}$ & $18.0^{*}$ \\
\hline
\end{tabular}

${ }^{*}=\mathrm{P}<0.05,{ }^{* \star *}=\mathrm{P}<0.001$ for differences between $\mathrm{N}$ and No N paddock averages for each column. Data were log transformed before analysis. 
cattle than sheep grazing (Williams \& Haynes 1994). In hill country, livestock exhibit camping behaviour results in nutrients from feed consumed on sloping land returned in excreta on flatter camp areas (Ledgard 2001). Measurements in hill country show that a large proportion of the dung and urine may be deposited on stock camping areas that occupy only a small fraction of the whole paddock (Saggar et al. 1988; Metherell 1994). Stock camps were observed in most of the paddocks in this study. Since the lysimeters were installed to avoid obvious stock camps, however, it is unlikely that the results have been unduly affected by stock camping behaviour.

\section{Conclusions}

The results of 3 years of monitoring indicate that feed supply can be significantly increased from late winter through to mid/late-spring and beyond with winter application of nitrogen fertiliser on hill country at Port Waikato. Pasture responses differed between years (14$19 \mathrm{~kg} \mathrm{DM} / \mathrm{kg} \mathrm{N}$ applied) and substantial differences were also noted between plots with different slopes/ aspects. Pasture botanical composition was not altered by nitrogen application. The pasture production benefits were associated with a considerable increase in $\mathrm{N}$ leaching. The variation in responses between years and between paddocks in both pasture production and nitrate leaching has been highlighted and justifies further monitoring. In addition, the site-specific nature of these responses should be considered in future farm management decisions.

\section{ACKNOWLEDGEMENTS}

Many thanks to Chris Boom, Greg Lambert, Anna Brooky, Gonzalo Carracelas and Alfredo Adler for their contributions to this project. We are grateful to two anonymous referees whose comments improved the quality of this paper. This project was funded by Ravensdown.

\section{REFERENCES}

Ball, P.R.; Luscombe, P.C.; Grant, D.A. 1982. Nitrogen on hill country. pp. 133-147. In: Nitrogen Fertilisers in New Zealand Agriculture. Ed. Lynch, P.B. New Zealand Institute of Agricultural Sciences.

GenStat 2007. 9th Edition, version 9.2.0.152 VSN International Ltd., Oxford, Great Britain.

Gillingham, A.G.; Gray, M.H.; Smith, D.R. 1998.
Pasture responses to phosphorus and nitrogen fertilisers on dry hill country. Proceedings of the New Zealand Grassland Association 60: 135-140.

Lambert, M.G.; Clark, D.A. 1986. Effects of late-autumn nitrogen application on hill country pastures and sheep production. Proceedings of the New Zealand Grassland Association 47: 211-215.

Lambert, M.G.; Mackay, A.D.; Devantier, B.P.; McDougall, D.B.; Barker, D.J.; Park-Ng, Z.A. 2003. Redefining the production potential of hill pastures using fertiliser nitrogen. Proceedings of the New Zealand Grassland Association 65: 35-40.

Ledgard, S.F. 2001. Nitrogen cycling in low input legume-based agriculture, with emphasis on legume/ grass pastures. Plant and Soil 228: 43-59.

Ledgard, S.F.; Brier, G.J; Gillingham, A.G.; Sheath, G.W. 1983. Influence of some soil and pasture components on the growth of hill country pastures 2 . Response to nitrogen fertilizer. New Zealand Journal of Experimental Agriculture 11: 251-256.

Ledgard, S.F.; Steele, K.W.; Feyter, C. 1988. Influence of time of application on the fate of ${ }^{15} \mathrm{~N}$ labelled urea applied to dairy pasture. New Zealand Journal of Agricultural Research 31: 87-91.

Luscombe, P.C. 1979. Nitrogen fertilizer responses on hill country pastures. Proceedings of the New Zealand Grassland Association 41: 155-162.

Metherell, A.K. 1994. A model for determining phosphate fertiliser requirements for pastures incorporating dynamics and economics. pp. 18-37. In: Proceedings of the workshop: The efficient use of fertilizers in a changing environment. Eds. Currie, L.D.; Loganathan, P. Fertiliser and Lime Research Centre, Massey University, Palmerston North.

Saggar, S.; Mackay, A.D.; Hedley, M.J.; Lambert, M.G.; Clark, D.A. 1988. The development of a nutrient transfer model to explain the fate of $\mathrm{P}$ and $\mathrm{S}$ in a grazed hill country pasture. pp. 262-278. In: Proceedings of the workshop towards the more efficient use of soil and fertiliser sulphur. Eds. White, R.E.; Currie, L.D. Fertiliser and Lime Research Centre, Massey University, Palmerston North.

Williams, P.H.; Haynes, R.J. 1994. Comparison of initial wetting pattern, nutrient concentrations in soil solution and the fate of ${ }^{15} \mathrm{~N}$-labelled urine in sheep and cattle urine patch areas of pasture soil. Plant and Soil 162: 49-59. 